\title{
The Conceptualisation of Tourism and Hospitality within a Public Administration Framework in South Africa: A Case study of a Tourism Provincial Administrative Authority in KwaZulu Natal
}

\author{
R. Balkaran \\ Durban University of Technology, South Africa \\ rishi@dut.ac.za
}

\begin{abstract}
Objectives of this paper are to: locate the study into a conceptual framework by conceptualising and clarifying Tourism and Public administration and management; Constitutional and legislative provisions relevant to the tourism and hospitality industries; National, provincial and local government administration with a view to locating Tourism and the Tourism Provincial Authority. Paper clarifies the intrinsic relationship between Government functions at national, provincial and local levels and the tourism and hospitality industries. The essence of the paper depicts the policy and a legislative framework formulated by government for the purposes of effective and efficient application to relevant structures at central, provincial and local levels. The welfare of the tourism and hospitality industries depend to a large extent on the delivery of services from public institutions at all levels of government.
\end{abstract}

Keywords: Tourism, hospitality, public administration, South Africa

\section{Introduction}

A study of the tourism and hospitality industry within the context of public administration requires a review of the fundamental linkages that uphold the concept tourism as well as a correlation of this finding to the various schools of management and management styles within public administration. It would be necessary to locate tourism within a public administration and management framework as well as establish its relevance within a national, provincial, and local context. It will, thereafter, be necessary to draw a clear relationship between the theory and practice of public administration, on the one hand and the administrative and management processes within the Tourism Provincial Authority on the other. Accordingly, the objectives of this paper are to - Locate the paper into a conceptual framework by conceptualising and clarifying the following aspects: Tourism and public administration and management; Constitutional and legislative provisions relevant to the tourism and hospitality industries; and National, provincial and local government administration with a view to locating Tourism and the Tourism Provincial Authority.

\section{Conceptualisation}

Government functions at national, provincial and local levels have an intrinsic relationship with the tourism and hospitality industries. Figure 1 outlines the theoretical framework of the paper in which the relationship between the tourism and hospitality industries and government is clarified. The framework accordingly locates the Tourism Provincial Authority as a provincial structure. The essence of the framework in Figure 1 depicts the policy and a legislative framework formulated by government for the purposes of effective and efficient application to relevant structures at central, provincial and local levels. The welfare of the tourism and hospitality industries depends largely on the delivery of services from public institutions at all levels of government. The implementation of the principles of Batho Pele directly influences the delivery of these services. Figure 1 locates public administration and management at every level of government and contextualises its role within the tourism and hospitality industries. 
Figure 1: Theoretical Framework of the Paper

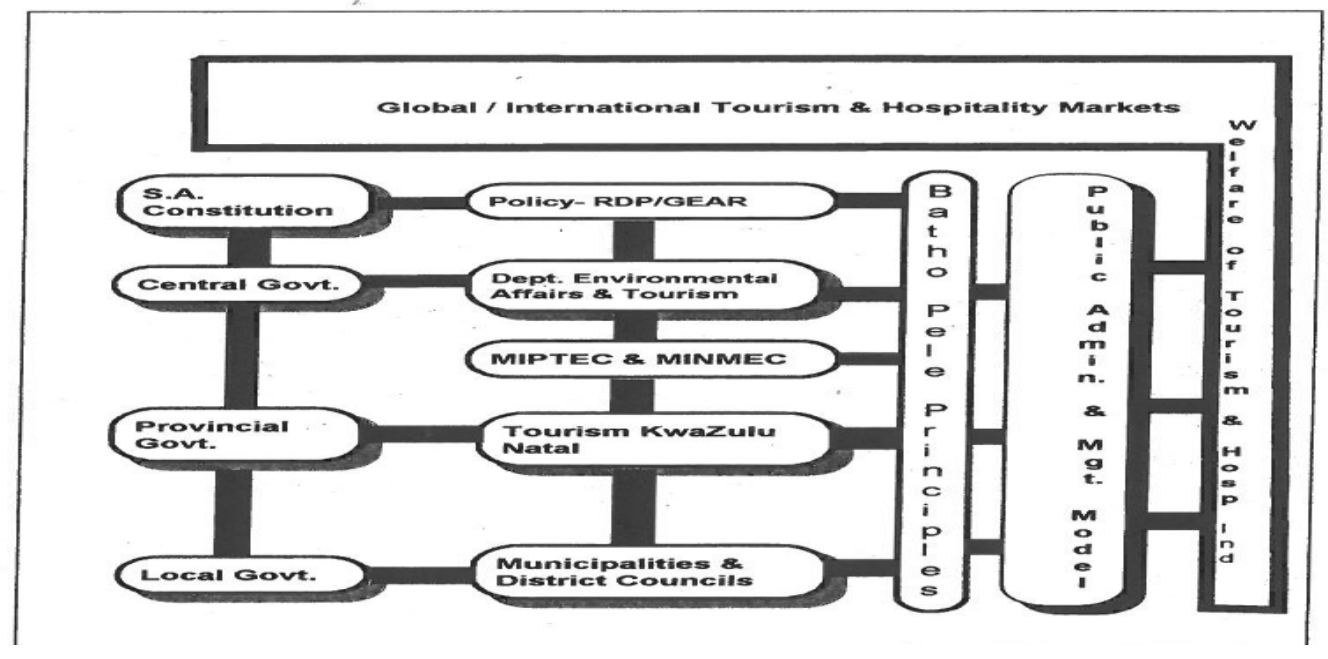

Constitutional and Legislative Provisions Relevant to the Tourism and Hospitality Industries: Chapter five, 85 (2b) of the Constitution of South Africa (Act 108 of 1996) enables the President together with members of Cabinet to develop and implement national policy. Chapter three, 40 (1) of the Constitution of South Africa (Act 108 of 1996) cites the structure of the government as having national, provincial and local spheres which are distinctive, but interdependent and interrelated. Schedule four of the Constitution of South Africa (Act 108 of 1996) reveals, amongst others, Tourism and Casinos, as the functional areas of concurrent National and Provincial Legislative competence. The Tourism Act (Act. No. 72 of 1993) makes provision for the promotion of tourism in South Africa. Section 27 of the act advances the promotion of legislation relating to the tourism industry including restaurants and other similar services. The Act further acknowledges the KwaZulu Natal province as a region as prescribed in Schedule1, Part 1, of the Constitution of South Africa (Act 108 of 1996). The Minister may also establish grading and classification schemes in respect of accommodation establishments. The Tourism Act (Act. No. 72 of 1993) empowers and further also provides for the formation of the South African Tourism Board which is charged with the following responsibilities: take measures in order to ensure that services which are rendered and facilities which are made available to tourists comply with the highest attainable standards; manage information and conduct research relating to tourism; and advise the Minister on tourism policy, either of its own volition or when requested to do so by the Minister. The Tourism Grading Council of South Africa (TGCSA) is mandated by government to advance quality assurance in the tourism industry. The TGSA is charged with implementing and managing a national grading scheme for operators in the tourism industry in South Africa (http://tourismgrading.co.za).

The White Paper on Development and Promotion of Tourism in South Africa (May 1996) sets out the parameters for the functioning of tourism within a national, provincial and local government context. Part VI of the White Paper on Development and Promotion of Tourism in South Africa (May 1996) sets out the role of national government as Facilitation and implementation; Co-ordination; Planning and policymaking; Regulation and monitoring; and development promotion.

The Minister of Environmental Affairs and Tourism is ultimately responsible for the government's management of tourism. The White Paper on Development and Promotion of Tourism in South Africa (May 1996) cites the tourism responsibilities of the Ministry as follows:

- to raise the profile of the tourism industry and put it in a position to compete with other sectors for funding and other national resources;

- to unleash the sector=s potential as a leader in wealth-creation and employment generation;

- to link the management of tourism with the critical environmental products that it uses viz. national parks, protected areas and cultural resources by formulating a cohesive development strategy and 
introducing specific environmental functions of monitoring, regulation and impact assessment where appropriate;

- to carry out a critical co-ordinating role among ministries whose mandates and activities directly impact on tourism - namely Ministers of Finance, Public Works, Transport, Trade and Industry, Arts, Culture, Science and Technology, Labour, Education, Home Affairs and Foreign Affairs; and

- To facilitate creative and strategic interaction between the tourism policy and policies guiding the management of land, water, energy and other natural resources.

Schedule 6 of the Constitution of South Africa (Act 108 of 1996) makes specific provision for tourism to be a provincial responsibility. In addition to the national responsibilities outlined above the provincial government also has to formulate policies that are typical to their areas. These policies must resonate with the national policy. In terms of the White Paper on Development and Promotion of Tourism in South Africa (May 1996):

The provincial governments, through provincial tourism organisations, have responsibility for marketing and promoting their destinations.

Environmental planning and land-use, product development, marketing, and promotion which are provincial functions, are further supported by local government (White Paper on Development and Promotion of Tourism in South Africa (May 1996). Local government plays an active role in policy implementation. The Kwa Zulu Natal Tourism Authority Amendment Act (Act No. 2 of 2002 Section 38) cites the specific functions for Municipal Tourism, some of the core areas being the following:

- Monitoring local tourism operators and establishments for compliance with provincial policies and legislation;

- promotion, marketing and development of local tourism within the metropolitan or district municipal area;

- alignment of local tourism marketing initiatives with provincial tourism marketing strategies;

- facilitation of the participation of local communities in the tourism industry;

- securing equitable distribution of local tourism resources within the area of the metropolitan, local or district municipality;

- adopting measures and programmes to transform the local tourism industry, including granting preferences to women and small , medium and micro-enterprises;

- implementing provincial tourism policy in conjunction with the Authority; and

- Any other functions specified in national or provincial policies or legislation.

The Kwa Zulu Natal Tourism Authority Amendment Act (Act No. 2 of 2002 Section 38) further draws caution to the fact that municipal policies must be consistent with national and provincial tourism policies and legislation and that municipalities may not develop or implement local tourism policies in a manner that is prejudicial to the interests of another municipality within the province or to the interests of the province itself. An illustration of the relationships between the various public sector organisations may be seen in Figure 2. The organogram displays alongside the structure of the National Department of Environmental Affairs and Tourism and various provincial ministries and departments, a system of executive bodies referred to by Keyser (2002: 215), as the destination organisations. 
Figure 2: Organisational Structure of Tourism South Africa Adapted from Keyser (2002:215)

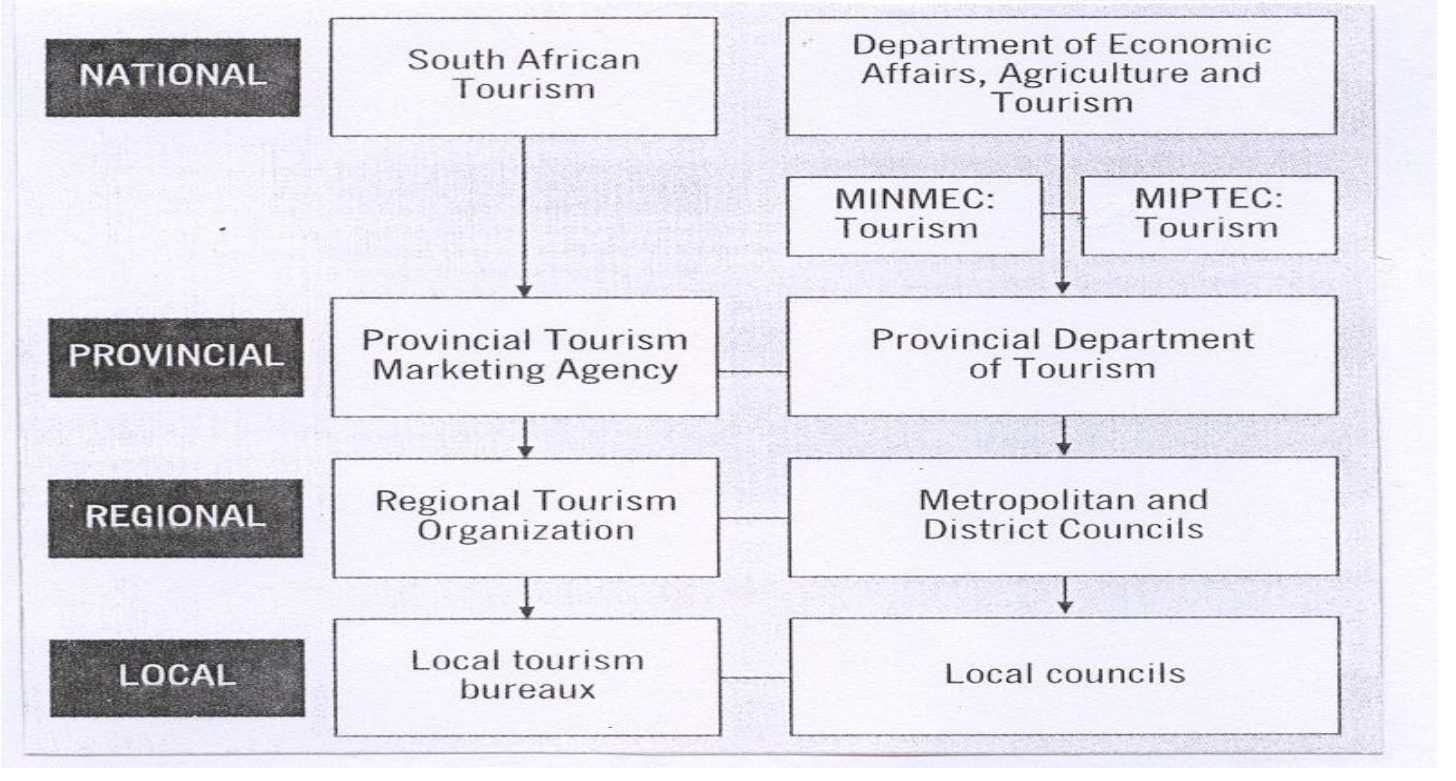

The Minmec Tourism is a forum comprising the National Minister of Environmental Affairs and Tourism and Members of the Executive Council (MECs) responsible for tourism in the nine provinces (Keyser 2002:214). National and provincial policies are decided at this level (Keyser 2002:214). The Miptec Tourism (Minmec Interprovincial Technical Committee) brings together national and provincial tourism officials, government department heads and CEOs of tourism authorities. The key role here is to coordinate provincial and national tourism affairs in support of Minmec Tourism (Keyser 2002: 214). Tourism KwaZulu Natal (TKZN) is located at the provincial level in Figure 1 and is responsible for positioning KwaZulu Natal nationally and internationally as Africa's premier tourism destination (TKZN Tourism Strategy 02/2003: 3).The Kwa Zulu Natal Tourism Authority Amendment Act (Act No. 2 of 2002 ) makes provision for the authority to establish regional tourism fora. The TKZN in terms if the Act may consider different regional boundaries after close consultation with relevant regional councils. Provision for regional tourism committees through elections is made. The White Paper on Transforming Public Service Delivery (Batho Pele White Paper) (1997) provides a platform for the implementation of the action plans of the Tourism KwaZulu Natal. The Batho Pele White Paper (1997) also provides a framework for the formulation of organisational policy. The Batho Pele principles may be closely associated with the normative foundations of public administration. The White Paper on Transforming Public Service Delivery (1997: 16) identifies the following as the key principles to transforming public service delivery:

Consultation: The White Paper on Transforming Public Service Delivery (1997:16) makes it compulsory for the Tourism KwaZulu Natal to consult on its current services as well as the basic services it is to provide for those who lack them. The abovementioned White Paper provides that the consultation, which must be done on a systematic and regular basis must be targeted at all current and future customers with the findings of such consultative process being published within and outside the organisation and a report being submitted to the Minister/MEC/ executive authority and the relevant Portfolio Committee.

Service standards: The Tourism KwaZulu Natal in terms of the White Paper on Transforming Public Service Delivery (1997: 16-17), is obliged to publish: their standards, the quality of their services and new services targeted in particular at the disadvantaged. The White Paper on Transforming Public Service Delivery (1997: 16-17) suggests the setting of baseline standards for services such as health and education. The Tourism KwaZulu Natal may fall in this category as tourism is a national function and certain baseline standards in 
respect of tourism can be established. The previously mentioned White Paper provides for the setting of precise, measurable, realistic standards for services, which standards must be approved by the Minister or MEC or the executing authority and published at the point of delivery of the services concerned. Further, provision is made in the White Paper on Transforming Public Service Delivery (1997: 16-17) for performance audits to be taken, results thereof to be published and unit standards to be explained with solution and deadlines in respect thereof being proffered.

Access: The White Paper on Transforming Public Service Delivery (1997: 16-17) makes it compulsory for all national and provincial departments to specify and set targets in respect of making its services accessible to the disadvantaged.

Courtesy: Courtesy, in terms of the White Paper on Transforming Public Service Delivery (1997:18), must be factored within the service standards and codes of conduct of provincial and national departments with managers being tasked with monitoring this aspect.

Information: The White Paper on Transforming Public Service Delivery (1997:19) makes specific reference to provincial and national department $=\mathrm{s}$ obligation to provide latest information in variety languages and include a name in the contact details.

Openness and transparency: Organisations like the Tourism KwaZulu Natal are required, in terms of the White Paper on Transforming Public Service Delivery (1997:20), to publish its reports to its constituency as well as to the national and provincial legislatures.

Redress: The White Paper on Transforming Public Service Delivery (1997:21) emphasises the need for heads of departments to take personal care over their complaints system with the principles of accessibility, speed, fairness, confidentiality, responsiveness, review and training being incorporated into their plans.

Value for money: A key requirement in terms of the White Paper on Transforming Public Service Delivery (1997: 22), for national and provincial departments, is to identify areas where savings could be made through efficient practice and service delivery improved with such savings.

National, Provincial and Local Government Tourism Management: The KwaZulu Natal Tourism Authority falls within the ambit of provincial government. The context within which provincial government operates can be seen in Figure 3.

Figure 3- Types and levels of institutions (Van der Walt 1997:141)

\begin{tabular}{|l|l|l|l|}
\hline $\begin{array}{l}\text { TYPES OF } \\
\text { INSTITUTIONS }\end{array}$ & \multicolumn{2}{|l|}{ Institutional levels } \\
\cline { 2 - 4 } & Central government & $\begin{array}{l}\text { Provincial } \\
\text { government }\end{array}$ & Local government \\
\hline Legislative Authority & Parliament & Provincial legislature & Municipal Council \\
\hline Executive authority & $\begin{array}{l}\text { Cabinet bureaucracy } \\
\text { (departments) }\end{array}$ & $\begin{array}{l}\text { Executive council } \\
\text { bureaucracy } \\
\text { (departments) }\end{array}$ & $\begin{array}{l}\text { Town clerk } \\
\text { Departments /divisions }\end{array}$ \\
\hline Judicial authority & $\begin{array}{l}\text { Constitutional Court } \\
\text { Supreme Court } \\
\text { courts Other courts } \\
\text { such as magistrates' courts }\end{array}$ \\
\hline
\end{tabular}


The reasons for government's involvement in tourism as pointed out by Jeffries (2001: 103) are as follows:

- $\quad$ states and their governments are drawn by the actual or proposed general legislation and policies, such as those governing taxation, into considering their specific effects on tourism; and

- Legislation, policies, institutions and programmes may be initiated and supported by government with tourism as their central focus.

This places into context the role of public administration and management.

\section{Public Administration and Public Management}

Fox, Schwella \& Wissink (1996: 03) defines administration as: The execution of activities by persons charged with common objectives.

They emphasize in this definition the importance of the environment particularly in relation to inputs and outputs. In addition to the above Cloete (1994: 12) refers to administration as an activity that:

... Can be divided into six main groups of processes/ activities/functions/, namely policymaking, organising, financing, staffing, (personnel provision and utilisation), determining work procedures, and the exercise of control over the progress being made to ensure that the objective will be attained.

The Cloete definition of public administration presents several shortcomings in respect of extreme oversimplification, close-ended approach, relevance, and reification (Schwella, 1991: 4).

The public sector has inherited much from the past apartheid practices of the previous government. Bayat \& Meyer (1994: 108), describes the Cloete Model as:

The administrative process approach is couched in severely simplistic terms and as such, it reduced the entire field of public administration in a simplistic manner to a small sub-section thereof i.e. administration. It was defended rather than criticised or improved by its followers. In other words, like all closed systems including apartheid, the administrative approach deliberately ignored anything that it regarded as threatening to its own existence.

Close-ended Approach: The classical school of management gave rise to the close-ended approach (Stoner: 1995:35) .The Tourism KwaZulu Natal is exposed to an array of environments, which would require constant monitoring, and therefore any close- ended approach would be unsuitable. Bayat\& Meyer (1994: 108), describe Cloete $=\mathrm{s}$ model as follows:

The introduction and reification of the administrative process approach was not merely a step in the wrong direction; it proved to be a mistake of massive proportions. This approach is presently re-established under the new name of management. The administrative process approach is a closed-ended approach.

Relevance: The organs of public administration were completely out of touch in respect of service delivery. The transforming public sector is still experiencing dire poverty, violence, crime, corruption and discrimination. This problem has been exacerbated by the narrow approach to public administration. The very nature and content of the Cloete model distorts critical research about the relationship between the system of public administration and the society in which it operates (Schwella 1991: 4).

Reification: The issues of co-operative governance become essential to organisations like Tourism KwaZulu Natal. Bayat\& Meyer (1994: 108), further criticise the Cloete Model as:

A A system $\Theta$ is an idea, mental construct, an abstract, symbolic interpretation of reality. As such, it is open to scrutiny to competition from other concepts, and to criticism. In the view of many academic adherents to systems theory, however, a system is much more than this. It becomes real. Instead of being a useful way of trying to get a handle on how the world works, it is simply assumed that there is only one handle and that disciplines such as public administration have a system as their focus. This is an intellectual slight of hand that has potentially catastrophic consequences. 
The concept Tourism and its various interpretations also attract to itself issues of the environment and their significance. The search for universally acceptable principles must be sensitised to the fact that the external environment can be negated. This then becomes typical of the Classical School which (Fox et al 1991: 10): ...emphasises a search for universally applicable principles of management. It focuses largely on internal efficiency and does not give significant attention to the management environment and factors in this environment.

Reductionism: Laws (1991) in Benett (2000: 39) depicts tourism as a process system of inputs, outputs and an intermediate stage. Reference, however, is made to the importance of the external environment. The functions of the Tourism KwaZulu Natal are related to the overall concept of public administration. This is consistent with the views of Fox, Schwella \& Wissink (1991: 4) who advance that:

The key components within public administration are, systems and structures designed to advance or facilitate governmental policy efficiently, within a particular environment. Public administration is therefore seen as a much broader concept in respect of its scope and as compared to public management.

It therefore becomes imperative to locate this study within a governmental management context and to highlight its place within the broad spectrum of public administration in South Africa.

The Public Management Model as advocated by Fox \& Meyer (1996:03) highlights the relationship between the environment and the public manager as well as the functions, skills and applications required by the manager.

The Public Management Model: The Public Management Model advances entrepreneurial practice and provides flexibility for the adaptation of public administration in all spheres of the public sector. The public sector is central to service delivery. The public management model is based on the open systems theory incorporating the contingency-based approach to management (Fox et al1991: 5).

The components of the public management model by Fox et al (1991: 5) are summarised as follows:

Environment: This consists of general and specific components. The general environment comprises the political, economic, social, cultural and technological aspects of the environment and the specific environment consists of suppliers, regulators, competitors and consumers. The effects of the environments are crucial to the public management function, skills, applications and aids (Fox et al, 1991: 4).

Public Management Functions: According to Fox et al (1991: 4), the functional components of the public management model are policy-making, planning, organising, leadership, motivation, control and evaluation.

Public Management Skills: Fox et al (1991: 5) are of the view that for a public manager to function effectively he must possess the following skills: competent decision-making, constructive negotiation, successful management of change and conflict, and negotiation skills.

Public Management Applications, Supportive Technology and Techniques: Fox et al (1991: 6) highlight the need for public managers to use available supportive technological aids and techniques such as computer technology and information management in the exercise of public management functions.

Tourism: Airey \& Tribe (2001: 287) describe tourism as:

A field of knowledge, which calls upon a number of disciplines to investigate and explain their area of interest. Airey \& Tribestate that this immediately characterises tourism and hospitality management as being multidisciplinary because they attract to themselves more than one discipline. They also identify these industries as interdisciplinary in that they can serve as a focal point whereby disciplines come together to present new insights and knowledge.

Keyser (2002: 16-20), refers to the evolution of the definition of tourism and concludes that the answer to the definition of tourism is not a straight-forward one and that academics seldom agree on an individual 
definition. It is however stressed that tourism has inherited several characteristics, which are fundamental to its identity. These characteristics are as follows (Keyser, 2002: 16-20):

- tourism involves people and their movement from areas of origin to destinations along routes;

- the movement is for less than twelve months;

- $\quad$ visits to places do not have to include an overnight stay;

- the exclusion of permanent residence or employment;

- $\quad$ the journey and the visit are the two elements of the tourism experience;

- the journey and stay usually occurs outside the area of residence;

- all tourism involves travel and not vice versa;

- the destination is where the activities and impact of tourists takes place;

- tourism involves the transfer of the purchasing power from the area of generation to the destination; and

- Pleasure or recreation is not the only reasons for tourism.

Cooper, Fletcher, Gilbert, Shepherd \& Wanhill (1998: 8-9) refer to the demand-side and the supply side of the definition of tourism. The demand- side encompasses the characteristics highlighted above (H. Keyser). The Asupply-side to the definition of tourism incorporates the tourism businesses, which partially or wholly serve tourists. Partial serving of tourists would imply the need to serve local residents. Cooper et al_(1998: 9) categorises business into two types in. Cooper et al_(1998: 10) state that the supply-side definition of tourism allows tourism to be compared with other economic sectors as well as provide an important conceptual framework for studying and researching tourism. Hughes (2000: 32) states that tourism may be considered an industry similar to those organisations that are required to supply transport, accommodation or souvenirs to tourists but consumers may not consider tourism to be an industry as he or she buys parts of the holiday from many different suppliers.

The Normative Guidelines of Public Administration that Impact on the Tourism KwaZulu Natal and Hospitality Industry.: Chapter 10 of the Constitution of the Republic of South Africa, 1996 (Act 108 of 1996 ) provides the basic values and principles applicable to every sphere of government, organs of state and public enterprises. The first principle focuses on maintaining a standard of professional ethics. Fox \& Meyer (1996:45) refers to ethics as:

... The process by which we clarify right and wrong and act on what we take to be right, i.e. a set or system of moral principles that is generally applied. Commitment to the public interest is a function of the institutional role of government managers and the ethos of public service that this role entails.

The second principle refers to efficient, economic and effective use of resources. Coetzee (1991: 67) avers that:

The crux of the notion of efficiency is that there must be one best way to do a job. The value of efficiency is important in public administration. Efficiency thus implies a definite standard; it is applicable to every activity in the public sector and can only be met through determined effort.

Bayat\& Meyer (1994: 39) assert that program effectiveness is:

... An open systems approach requires public administration to be in equilibrium with the environment and to be functioning in harmony with the general and particular values and concepts of the community. This implies the execution of a programme in such a manner that it satisfies the values and needs of individuals and the community both efficiently and effectively.

The fundamental challenge, however, remains in the delicate balance between the effectiveness, efficiency and economic levels. Bayat\& Meyer (1994: 39) also emphasised the following:

- public administration must be development-oriented;

- the provision of impartial, fair, equitable and unbiased services;

- the fostering of transparency with timely, accessible and accurate information to the public;

The basic principles above set a clear tone for the conduct of public officials within the Tourism KwaZulu Natal and further inform the nature of their decisions at all levels of the organisation.

This also indicates a marked shift in respect of the approach to public administration. This paradigm shift is also representative of the general environment that surrounds public administration. 
The lessons learnt from the Public Management Model reinforce the need for the application of change management strategies in order to rethink and re-develop public administration and management within the Tourism KwaZulu Natal.

\section{Public Management Model and Its Relevance to the Operations of the Tourism Kwazulu Natal}

The external environment of tourism organisations is a turbulent one and Tribe (1997:55) characterises the external environment as dangerous, diverse, difficult and dynamic. The KwaZulu Natal (KZN) province has brought in more than six million foreign tourists for the period January to December 2002 which was 11.1 percent more than the previous year for the same period (Foreign Tourists: www.zulu.org.za). The most recent statistics pertaining to the KZN province are for the period January to February 2003 which reflect the province as having received 1095931 foreign tourists. This is 8.1 percent more than the previous year for the same period (Foreign Tourists: www.zulu.org.za). Discussion on the relevance of the Public Management Model to the Tourism KwaZulu Natal will be presented under the following headings:

Public Management and the Environment: The goods and services within the tourism and hospitality industries are extremely sensitised to the changes within the environment. Cullen (2000: 174) highlights the essential features and difference between these goods and services as relating to intangibility and perishes ability. He talks of goods being tangible and services being intangible and refers to goods being measurable whilst services would be difficult to measure precisely. In respect of perish ability; he says this is very evident in services. An example would be that one might be unable to store an unused hotel room from one night to the next. Other goods and products, on the other hand, may be stored and sold later without incurring losses (Cullen 2000: 174). Certain products or goods, within hotels are identified as homogenous whilst services, on the other hand, are heterogeneous Cullen (2000: 174). He cites the standardisation of televisions within the rooms as part of the goods as being homogenous whilst the provision of meals would be heterogeneous as the meals differ from one guest to another depending on their needs. Cullen (2000: 174) states that the production of goods can be separated from the consumption of goods. He points out those services are produced and consumed at the same time. A counter point is also made in respect of the modern day production and storage technology where food services do not have to be produced and consumed at the same time. The issues in relation to the complexities of the nature of the goods and services of the tourism and hospitality industries are now evident. The volatile nature of the environment poses enormous challenges.

\section{Figure 4: Mutual Influence of Public Administration and the Environment and the Ongoing Interaction (Du Toit et al 1998:158)}

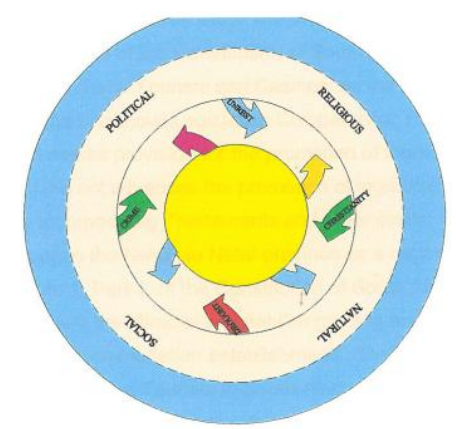

The essence of the Public Management Model is the fact that it draws substantial significance to the environment and its interaction with the organisation and managerial decision making Fox et al (1991: 05). This is reinforced by the environmental variables that contribute significantly towards the development of an approach applicable to public management. Whilst public organisations are not managed for profit, as in the 
case of private institutions, they must, however, be managed for performance. The contingency based approach highlighted in Stoner et al (1995: 48), provides a sound basis for the implementation of the Public Management Model. The Tourism KwaZuluNatal is exposed to the political, social, technological, and economic environments, which constantly interact and affect both positively and negatively on their overall performance. Du Toit et al (1998: 166) describe this phenomenon:

As the natural environment changes, the whole environment changes. Public administration and management have to adapt, which leads to further changes and adaptations.

A clear analogy of the influence of the environment may be seen in Figure 4.

Public Management Functions within the Tourism KZN: Functions such as policy-making, planning, organising, leadership, motivation, control and evaluation, amongst others, are part of the functional component of the public management model reflected in Figure 4. The chief source of policy within the TKZN would emanate from legislation like the Tourism Act (Act. No. 72 of 1993), the White Paper on Development and Promotion of Tourism in South Africa (May 1996) and the Kwa Zulu Natal Tourism Authority Amendment Act (Act No. 2 of 2002). The focus of the PFMA, which is around effective, efficient, and economical management, commands the need for short, medium and long-term planning, all of which require a contingency based management approach.

Figure 5: Applied Public Management Model to the Tourism KwaZulu Natal

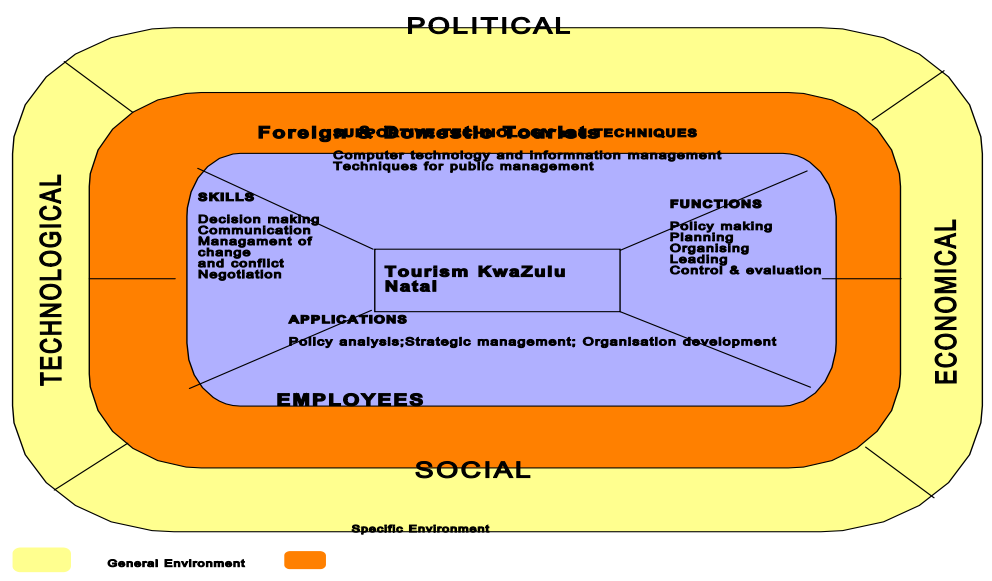


Public Management Skills within the Tourism KZN: The management of the general and specific environments within the TKZN would present many varied challenges. These challenges would take the form of interactions with the media, public sector liaisons with, for instance the Auditor General and private sector liaisons with commercial banks and foreign investors and keeping abreast of the provincial needs. Ensuring that consultants and agencies are delivering services in accordance with agreed standards are part and parcel of the public official=s task at the TKZN. These tasks and challenges require the possession of skills related to decision-making, constructive negotiation, management of change and conflict resolution.

Applications, Supportive Technology and Techniques within the Tourism KZN: Tourism KZN presently develops, manages and maintains a dynamic, relevant and accessible tourism information management system (database) and research programme for the province (Tourism Strategy 2003-2006: 18). Further these systems are linked to national and global networks that furnish information on trends, developments, competitive information, tourism products and market intelligence and this database is also linked to the provincial and local stakeholders for their effective planning and decision making (Tourism Strategy 20032006:18). The functions of policy making, planning and organising are considered within the framework of policy analysis, strategic management and organisational development. The Tourism Strategy (2003-2006: 4) states that the TKZN=s focus will be to position KZN as a globally competitive tourist destination and to expand the tourism economy and employment opportunities between 2003 and 2006. The strategy aims to align tourism institutions, avoid duplication, reduce costs and advance co-operative governance. The Vision, Mission, Guiding principles and values, objectives and goals and targets of the Tourism Strategy 2003-2006, are examples of refined products of policy analysis that stem from broader national and global trends.

\section{Conclusion}

The key to the success of the Public Management Model is vested in the organisations strategic framework. This strategic framework would be responsible for translating public policy and legislation into effective, efficient and economic realisable goals and objectives that would in turn require implementation. This would involve the public management functions of decision making, organisation, budgeting, negotiations etc.

\section{References}

Airey, D. \& Tribe, J. D. A. (2000). In Search of Hospitality, Theoretical Perspectives and Debates. Oxford: Butterworth- Heinemann.

Bayat, M. S. \& Meyer, I. H. (1994). Public Administration Concepts, Theory and Practice. Midrand: Southern Book Publishers.

Bennett, J. A. (2000). Managing Tourism Services. Pretoria: Van Schaik Publishers.

Cloete, J. J. N. (1994). Public Administration and Management. Pretoria: JL Van Schaik.

Cooper, C., Gilbert, D., Fletcher, J., Wanhill, S. \& Shepherd, R. (1998). Tourism Principles and Practice (Second Edition). New York: Addison Wesley Longman Publishing.

Cullen, P. (2000). Economics for Hospitality Management. London: Thompson Business Press.

Dale, A., Arber, S. \& Procter, M. (1988). Doing Secondary Analysis. London: Unwin Hyman Ltd.

Du Toit, D. P. F., Van der Walt, G., Bayat, M. S. \& Cheminais, J. (1998). Public Administration and Management for Effective Governance. Cape Town: Juta \& Co.

Finnemore, M. (1998). Introduction to Labour Relations in South Africa- Sixth Edition. Durban: Butterworths. Fox, W., Schwella, E. \& Wissink, H. (1991). Public Management. Kenwyn: Juta \& Co. 
Fox, W. \& Meyer, I. (1996). Public Administration Dictionary. Eppindust II: Juta \& Co.

Hughes, H. (2000). Arts Entertainment and Tourism. Oxford: Butterworth-Heinemann.

Jeffries, D. (2001). Governments and Tourism. Oxford: Butterworth-Hienemann.

Keyser, H. (2002). Tourism Development. Cape Town: Oxford University Press.

Stoner, J. A. F., Freeman, R. E. \& Gilbert, D. R. (1995). Management (6 ${ }^{\text {th }}$ Edition). New Jersey: Prentice Hall International Editions.

Tribe, J. (2001). Corporate Strategy for Tourism. London: Thomson Learning.

Tribe, J. (2000). The Economics of Leisure and Tourism (Second Edition). Oxford: Butterworth- Heinemann.

Van Der Waldt, G. T. \& Helmbold, R. (1995). The Constitution and a new Public Administration. Cape Town: Juta \& Co.

\section{Government Publications}

\section{Acts of Parliament}

The South African Constitution, 1996.

Employment Equity Act 55 of 1998.

Employment Equity Act 55 of 1998.

Skills Development Act 97 of 1998.

Tourism Act (Act No. 72 of 1993).

KwaZulu Natal Tourism Act (Act No. 11 of 1996).

KwaZulu Natal Tourism Amendment Act (Act No. 2 of 2002).

The Hotels Act of 1965 (Act no. 70 of 1965).

Lotteries and Gambling Board Act (Act No. 210 of 1993).

Public Finance Management Act (Act No. 1 of 1999).

White Paper on the Development and Promotion of Tourism May 1996.

White Paper on Transforming Public Service Delivery (Batho Pele White Paper), October 1997.

\section{Unpublished Sources}

\section{Official Documents of the Tourism KwaZulu Natal}

Tourism KwaZulu Natal Tourism Strategy 2003-2006.

KwaZulu Natal Tourism Statistics (Third Edition) 2002.

Tourism KwaZulu Natal Financial Statements as at end March 2002.

Report of the Auditor General to the members of the KwaZulu Natal Provincial Legislature, (year ending March, 2002).

Report on the Size of the KwaZulu Natal Market, June - September 2002 - Tourism KwaZulu Natal \& Durban Unicity (December 2002).

Tourism Product Development Strategy (March, 2002).

Tourism KwaZulu Natal Annual Report (2001/2002).

Draft summary of the Tourism KwaZulu Natal Tourism Product Development Strategy (2003).

Tourism KwaZulu Natal Chairman's Report (2002).

South African Tourism Growth Strategy, May 2002. Draft Action Plan 2003 \& 2004 (14/02/2003.

\section{Internet Sites}

Tourism KwaZuluNatal: www.zulu.org.za.

British Broadcasting Corporation News: http://newsbbc.co.uk.

South African Tourism: www.safrica.net.

Fair Share: www.uwc.ac.za.

Fedhasa: www.fedhasa.co.za.

Tourism Grading Council :( http://tourismgrading.co.za). 